\title{
РЕАЛИЗАЦИЯ ИНТЕРАКТИВНЫХ МЕТОДОВ ОБУЧЕНИЯ В ПРОЦЕССЕ ПОДГОТОВКИ СПЕЦИАЛИСТА ПО ПРОФИЛЮ В НЕЯЗЫКОВОМ ВУЗЕ (НА ПРИМЕРЕ ДИСЦИПЛИНЫ ИНОСТРАННЫЙ ЯЗЫК)
}

\section{IMPLEMENTATION OF INTERACTIVE TEACHING METHODS IN THE PROCESS OF TRAINING A SPECIALIST IN A NON- LINGUISTIC UNIVERSITY (ON THE EXAMPLE OF THE DISCIPLINE FOREIGN LANGUAGE)}

I. Gotovtseva I. Kapustin

V. Korzyakov I. Lyamina I. Avdeeva

Summary: The article deals with the problem of practical implementation of interactive teaching methods in the process of training a specialist in a non-linguistic University by means of the foreign language discipline. The article provides a detailed analysis and review of the main interactive methods and methods of teaching students a foreign language in a non-linguistic University. The interactive methods used in this study in teaching students a foreign language in a non-linguistic University can serve as a basis for the development and subsequent testing of e-learning courses based on a distance learning system. In the conditions of intensification of the learning process, interactive teaching methods are of particular importance, contributing to the activation of educational and cognitive activity of students, increasing the level of motivation and interest in the learning process, developing independence and creative activity.

Keywords: interactive teaching methods, non-linguistic University, foreign language tools, case-study method, role-playing game, brainstorming.

Готовцева Ирина Петровна

К.б.н., доцент, Российский Государственный Аграрный Университет - Московская Сельскохозяйственная Академия имени К.А. Тимирязева

Капустин Иван Владимирович

старший преподаватель, Российский Государственный Аграрный Университет - Московская Сельскохозяйственная Академия имени К.А. Тимирязева

Корзяков Вячеслав Алексеевич

старший преподаватель, Российский

Государственный Аграрный Университет - Московская Сельскохозяйственная Академия имени К.А. Тимирязева,

istratown@mail.ru

Лямина Ирина Мажитовна

старший преподаватель, Российский

Государственный Аграрный Университет - Московская Сельскохозяйственная Академия имени К.А. Тимирязева

Авдеева Ирина Владимировна

К.и.н., доцент, Российский Государственный Аграрный Университет - Московская Сельскохозяйственная Академия имени К.А. Тимирязева

Аннотация: В представленной статье рассмотрена проблема практической реализации интерактивных методов обучения в процессе подготовки специалиста по профилю в неязыковом вузе средствами дисциплины иностранный язык. В рамках статьи проводится подробный анализ и обзор основных интерактивных методов и способов обучения студентов иностранному языку в неязыковом вузе. Примененные в настоящем исследовании интерактивные методы в обучении студентов иностранному языку в неязыковом вузе могут выступать в качестве основы для разработки и последующей апробации электронно-обучающих курсов на базе системы дистанционного обучения. В условиях интенсификации процесса обучения интерактивные методы обучения приобретают особое значение, содействуя активизации учебно-познавательной деятельности студентов, повышая уровень мотивации и интереса к процессу познания, развивая самостоятельность и творческую активность.

Ключевые слова: интерактивные методы обучения, неязыковой вуз, средства иностранного языка, метод кейс-стади, ролевая игра, брейнсторминг.

обратить особое внимание на качество образования, одним из слагаемых которого выступает мотивационная активность студентов. Среди множества разнообразных педагогических технологий, существующих в ЕОП на сегодняшний день, следует отметить широкое 
применение интерактивных методов (далее - ИМ), инновационных технологий, среди которых: case-study (кейсстади - метод учебных кейсов или ситуаций), brainstorm (брейнсторминг- метод «мозгового штурма») и методика ролевой деятельности (проекты и игры), способные оказывать стимулирующее воздействие на мотивационную сферу обучающихся в процессе их реализации в образовательном процессе вуза[1, с.67].Опираясь на сказанное, была сформулирована чель настоящего исследования, которая заключалась в разработки технологии реализации интерактивных педагогических методик в прочессе подготовки будущих выпускников неязыкового вуза средствами иностранного языка, основанных на результатах их сравнительно-сопоставительного анализа.

\section{Теоретическое обоснование проблемы исследования}

В ходе сравнительно-сопоставительного анализа в качестве основных критериев выступали: 1) степень влияния ИМ на уровень успеваемости студентов по дисциплине «Иностранный язык»; 2) индивидуальные особенности контингента обучающихся; 3) учет «временных затрат» педагога и студента; 4) учет сложности реализуемой ИМ. Остановимся более подробно на рассмотрении каждой из вышеназванной ИМ с позиций названных критериев, не затрагивая их классификацию и общеизвестные характеристики [4, с.55-56].

В качестве основной идеи метода учебных кейсов или ситуаций выступает поиск обучающимися решения конкретной проблемы или учебной задачи, в связи с чем, данный метод принято рассматривать в рамках поисково-исследовательских технологий [2, с.312]. В качестве основных целей и задач метода учебных кейсов или ситуаций выступают: 1) развитие аналитического мышления; 2) развитие практических навыков работы с информацией; 3) развитие навыков разработки управленческих решений; 4) овладение навыками и приемами всестороннего анализа ситуаций из сферы профессиональной деятельности; 5) отработка умения востребовать дополнительную информацию, необходимую для уточнения исходной ситуации; 6) приобретение навыков применения теоретических знаний для решения практических задач [6, с.254]. Не останавливаясь на описании общеизвестного в настоящее время метода, перейдем к описанию непосредственного его использования в рамках настоящего исследования.

В нашем случае, в контексте цели настоящего исследования рассматриваемый метод применялся на занятиях по дисциплине «Профессиональный иностранный язык», так как, с нашей точки зрения, он, как нельзя лучше, содействует качественному усвоению, как профес- сиональной лексики, так и изучаемых грамматических структур[12, с.37]. Нами были использованы следующие типы проблемной ситуации: 1) выбор из системы усвоенных знаний только тех, которые необходимы для решения проблемы; 2) обнаружение несоответствия между имеющимися знаниями и новыми фактами[8].

Остановимся более подробно на рассмотрении первого типа проблемной ситуации на занятиях профессионального иностранного языка со студентами агрономического факультета. В соответствии с программой дисциплины «Профессиональный иностранный язык» студенты изучают профессиональную лексику, связанную с названиями основных сельскохозяйственных культур и их биологическими особенностями. Преподаватель ставит студентов перед многообразием выбора из известных им культур тех, которые лучше всего произрастают в прохладном или, наоборот, в теплом климате. Решая данную проблемную ситуацию, студенты используют следующую профессиональную лексику «ln crop selection the climate is the most important environmental factor. The crops which grow best under relatively cool or moderate conditions include wheat, oats, barley, rye, potatoes, sugar beets, red clover, and many grasses. Corn, cotton, sorghum, rice, soybeans do best under warmer conditions».

Проблемную ситуацию первого типа можно создать на занятиях профессионального иностранного языка со студентами зооинженерного факультета при изучении лексики, связанной с разведением пчел (Bee-keeping). При изучении английского текста о способах содержания пчелиной семьи преподаватель создает следующую проблемную ситуацию: «At the end of the flowering season the honey yield from two identical bee-houses was $65 \mathrm{~kg}$ and $12 \mathrm{~kg}$. What is the reason?». Студенты анализируют известные им причины недобора меда. Так как условия содержания этих двух ульев были одинаковые, студенты приходят к выводу, что основной причиной недобора могло явиться разное время установки рамки в улье. Причиной недобора меда явилась более поздняя установка рамки в один из ульев - «the main factor is the time of placement of a honey comb in a bee-house. The later the time of comb placement, the poorer the honey yield».

На занятиях профессионального иностранного языка по теме «Фотосинтез» со студентами агрономического факультета преподаватель создает проблемную ситуацию второго типа, рассказывая, что при выращивании растений огурца одного и того же сорта при одинаковом хорошем освещении, были получены растения с разной окраской листьев - от темно-зеленой до бледно-зеленой и желтоватой. Студенты на предыдущих занятиях изучали тематическую лексику, связанную с ролью хлорофилла в процессе фотосинтеза, и должны ответить 
на вопрос «What is the reason of color change». Студенты анализируют возможные причины изменения окраски листьев - mutation, genetic trait, lack of water, - и приходят к выводу, что единственной причиной является недостаток минеральных удобрений - lack of minerals.

Далее, остановимся на организации занятий профессиональным иностранным языком с применением метода «мозгового штурма» (брейнсторминг), второго по значимости в иерархии ИАМО [10, с.536].В качестве примера, рассмотрим учебное занятие по теме «Шумовое загрязнение является третьим по значимости фактором окружающей среды по плохому воздействию на здоровье людей», проведенного со студентами-экологами на занятии «Иностранный язык».

Предварительно, непосредственно перед занятием группа студентов была разделена на две подгруппы. Студентам, входящим в состав первой группы, было предложено создать презентацию, содержащую в себе информацию по заданной темой занятия проблеме, которая демонстрировалась учащимся второй группы с целью проведения собственного исследования. Кроме того, студентам второй группы были предложены для обсуждения вопросы, ориентирующие их на поиск дополнительной информации с целью детализации исследуемой темы.

В ходе занятия, студентами первой группы была подготовлена и продемонстрирована презентация «Noise pollution in Vladikavkaz», при создании которой использовался материал анализа шумового загрязнения г. Владикавказа по данным шумового мониторинга, проведенного студентами под руководством преподавателя. Замеры уровня шума были осуществлены по 15 точкам, информацию с которых «снимали» 3 раза в день: 6-9 ч утра, 12-15 ч дня с 18-21 ч вечера, что позволило создать три карты шумового загрязнения города в разное время суток, и сделать вывод о наличии превышения нормативов шума в различных районах города.

Одновременно, студенты второй группы осуществляли поиск дополнительной информации по ранее предложенным им вопросам в рамках исследуемой проблемы: 1) Why are people so concerned about noise pollution problems? 2) What factors concerning noise should be taken into account in environmental impact assessments in noise estimate studies? 3) Are there any noise maps and action plans prepared in our republic to follow the instructions of Directive of the European Parliament and of the Council of June relating to the assessment and management of environmental noise? 4) Have any laws and strategic documents been adopted, over the past period, in areas of environmental impact assessment, strategic environmental impact assessment, and quality of air, waste management, and water management, control of industrial pollution, chemicals, and noise in our republic? 5) Do you think that creation of a kind of sound filter able to preserve ourselves from noise pollution can solve the problem? 6) What recommendations can be made to ask local authorities to provide relevant proposals regarding environmental impact assessment and noise reduction? 7) High noise levels can contribute to cardiovascular effects in humans and an increased incidence of coronary artery disease, can't they?

По окончании осуществлялось совместное обсуждение с высказыванием индивидуальных и групповых идей студентов обеих групп, преследующих цель установления вариантов улучшения экологической ситуации в городе, в частности: 1) using dead-end streets and car-free malls as sites for residential complexes; 2) depressing freeways and arterial roads below the level of adjoining residential areas; 3 ) using roadside noise barriers; 4) creating maximum separation between roads and new buildings; 5) sitting high-rise buildings at the front of a development, thereby providing acoustic shielding for any low-rise buildings behind them; 6) using natural topographic features to the best acoustic advantage.

В ходе реализации данного метода на занятии по иностранному языку, были выявлены некоторые сложности, в частности: 1) ограниченное учебное время; 2) недостаточный уровень подготовленности педагогов к реализации данных методов при изучении иностранного языка и к повышению мотивационной активности студентов; 3) низкий уровень начальных знаний по иностранному языку из-за дифференциации подходов к обучению по предмету в школах. Однако, наравне с недостатками, были выявлены и ряд достоинств, которыми обладает метод мозгового штурма при его использовании в обучении студентов иностранному языку, среди них: 1) поэтапное освоение курса учебной дисциплины «иностранный язык»; 2) более интенсивное погружение в языковую среду.

Далее, представим разработку занятия, выстроенного в соответствии с методикой ролевой деятельности (проекты и игры). Опираясь на данные, представленные в научной и научно-методической литературе, раскрывающие специфические особенности названной методики, можно заключить, что структура подобных проектов остаётся «открытой» до завершения работы, в ходе которой все действия её участников осуществляются в соответствии с выбранными ролями, согласованные с характером и содержанием проекта. В качестве примера, мы приведем занятие (ролевая игра), организованное нами в ходе исследования, по теме «Презентация компании». Организационный этап данного занятия включал в себя разделение студентов по группам-компаниям (по 4 че- 
ловека в каждой), каждая из которых имела своего директора, бухгалтера и двух рекламных агента. В задачи студентов входило разработка наименования и логотипа своей компании, расчет бизнес-плана, позволяющего достичь заданного значения прибыли, организация рекламы и формирование финансовой документации. Сама реализация проекта осуществлялась на протяжении 3 занятий с итоговой презентацией компании [5]. В нашем случае, занятия организовывались в рамках темы «Разработка и продвижение нового программного обеспечения».

Как было указано нами ранее, ролевая игра является более простым по сравнению с деловой игрой, методом активного обучения, требующей меньших временных затрат на разработку и непосредственную организацию в рамках образовательного процесса. Основным признаком ролевой игры является наличие конкретной проблемы, требующей разрешения и распределение ролей. В проведенной нами ролевой игре по разработке технологии возделывания овощных культур студенты выступали в роли агронома-селекционера, агронома агрохимика, агронома по защите растений, агрономатехнолога. Роли распределяли между студентами для достижения намеченной сельскохозяйственной компанией цели. В ходе игровой деятельности, в рамках названного проекта, студенты осуществляли деятельность по коллективной разработки предложений, ориентированных на модернизацию технологии выращивания в тепличном хозяйстве новых гибридов томатов.

Для решения поставленной задачи, студенты вынуждены были обратиться к поиску дополнительного информационного материала, осуществлять коллективное обсуждение выдвигаемых идей (дискуссии), направленных на решение поставленной перед ними задачи. По окончанию своей работы, студенты каждой группы подготавливали сообщения, высказывали свои мнения и совместно обсуждали их с обязательным подведением итога - принятием единого решения.

Данная ролевая игра проводилась на занятии профессионального иностранного языка со студентами факультета садоводства и ландшафтной архитектуры с целью закрепления и контроля лексического и грамматического материала по таким пройденным темам, как «The biology of tomato», "Commercial production of green-house tomatoes», "Growing the transplants», «Plant protection», «Breeding for resistance to diseases and insect pests».Участники группы агрономов-селекционеров выступали с сообщениями о биологии растений томатов:«The types of root system», «Growth habit», «Response to light intensity», «Early and total yield potential», «New tomato hybrids best adapted to growing in green-house conditions», «Climatic conditions», «Biological characteristics».

Студенты группы агрономов-агрохимиков готовили сообщения о роли питательных веществ для роста и развития растений и требованиях растений томатов к минеральному питанию на разных стадиях развития «Role of nitrogen, potassium, phosphorus, sodium and microelements in plant growth and development», «The effect of the excess and deficit of macro- and microelements on tomato plant growth and fruiting», «Application of fertilizers at different stages of tomato plant growth and development».

Студенты группы агрономов по защите растений представляли информацию о болезнях и вредителях томатов в условиях защищенного грунта, способах обеззараживания субстрата, семян, химических препаратах для борьбы с болезнями и вредителями, биологических методах защиты растений: «Tomato fungal, viral and bacterial diseases, causing agents», «Disease symptoms, such as wet rot, vessel bacterios is, wilting, growth retardation, flower and fruit drop», "Soil sterilization - steaming, flooding, application of chemicals to destroy weed seeds, insects, nematodes, disease-producing fungi, bacteria and viruses», «Biological pest control», "Genetic resistance to pests and diseases», «Cultural and physical pest and disease control».

Студенты группы агрономов-технологов рассказывали о технологиях беспочвенного выращивания растений томатов, технологиях выращивания рассады, технологиях выращивания растений томатов в пленочных и остекленных теплицах:«The ebb-and-flow system, nutrient film technique, rockwool, drip irrigation, perlite bag or perlite bucket, standing-aerated, aeroponics and others», «Growing the transplants - temperature, light, water and nutrition requirements», «Methods of watering transplants to prevent the spread of diseases», "Enrichment of the atmosphere with carbon dioxide to accelerate transplant growth rate», "Supplemental artificial light during day light hours is an essential method to increase the yield of fruit», «Tomatoes with determined growth habit for film houses and indetermined growth habit for glass houses».

Оценка осуществленной деятельности каждой группы производилась самими студентами. Для оценки работы группы и каждого участника была разработана оценочная шкала, каждый балл в которой соответствовал ряду критериев (см. таблицу 1).

К основным достоинствам примененного нами метода ролевой деятельности (проекты и игры) были отнесены следующие:1) экономия учебного времени; 2) более низкие требования к уровню входных знаний, сформированных умений и навыков студентов; 3) полная автономность от этапов обучения иностранному языку. 
Таблица 1.

Критерии оценки ролевой игры

\begin{tabular}{|c|c|c|c|c|}
\hline Оценка & Отлично & Хорошо & Удовлетворительно & Неудовлетворительно \\
\hline 1 & 2 & 3 & 4 & 5 \\
\hline Содержание & $\begin{array}{l}\text { Соблюден объем высказы- } \\
\text { вания. Высказывание соот- } \\
\text { ветствует теме; отражены } \\
\text { все аспекты, указанные в } \\
\text { задании, стилевое оформле- } \\
\text { ние речи соответствует типу } \\
\text { задания, аргументация на } \\
\text { уровне, нормы вежливости } \\
\text { соблюдены }\end{array}$ & $\begin{array}{l}\text { Неполный объем выска- } \\
\text { зывания. Высказывание } \\
\text { соответствует теме; не от- } \\
\text { ражены некоторые аспек- } \\
\text { ты, указанные в задании, } \\
\text { стилевое оформление речи } \\
\text { соответствует типу задания, } \\
\text { аргументация не всегда на } \\
\text { соответствующем уровне, } \\
\text { но нормы вежливости со- } \\
\text { блюдены }\end{array}$ & $\begin{array}{l}\text { Тема раскрыта не полностью, } \\
\text { значительные нарушения в } \\
\text { логике подачи материала }\end{array}$ & $\begin{array}{l}\text { Тема практически не раскры- } \\
\text { та, нет логических связей }\end{array}$ \\
\hline Грамотность & Грамотная речь & $\begin{array}{l}\text { Незначительные граммати- } \\
\text { ческие погрешности }\end{array}$ & $\begin{array}{l}\text { Много грамматических оши- } \\
\text { бок, но речь понятна }\end{array}$ & $\begin{array}{l}\text { Очень много ошибок, за- } \\
\text { труднено понимание речи }\end{array}$ \\
\hline Коммуникативные умения & $\begin{array}{l}\text { Адекватная естественная } \\
\text { реакция на реплики собесед- } \\
\text { ника. Проявляется речевая } \\
\text { инициатива для решения } \\
\text { поставленных коммуника- } \\
\text { тивных задач }\end{array}$ & $\begin{array}{l}\text { Участник уверенно осу- } \\
\text { ществляет коммуникацию, } \\
\text { однако не всегда проявляет } \\
\text { речевую инициативу для } \\
\text { решения поставленных ком- } \\
\text { муникативных задач }\end{array}$ & $\begin{array}{l}\text { Участник не совсем уверенно } \\
\text { осуществляет коммуника- } \\
\text { цию, не проявляет речевую } \\
\text { инициативу для решения } \\
\text { поставленных коммуника- } \\
\text { тивных задач }\end{array}$ & $\begin{array}{l}\text { Участник неуверенно осу- } \\
\text { ществляет коммуникацию, } \\
\text { коммуникация затруднена }\end{array}$ \\
\hline
\end{tabular}

Таблица 2

Результаты успешности обучения в ЭГ и КГ группах в процентном соотношении между традиционной и билингвальной технологиями на протяжении 8 этапов педагогического эксперимента, \%

\begin{tabular}{|l|c|c|c|c|c|c|c|c|}
\hline \multirow{2}{*}{ Группа } & \multicolumn{10}{|c|}{ Этапы } \\
\cline { 2 - 9 } & 1 & 2 & 3 & 4 & 5 & 6 & 7 & 8 \\
\hline ЭГ & $10 / 90$ & $10 / 90$ & $60 / 40$ & $30 / 70$ & $10 / 80$ & $5 / 55$ & $10 / 90$ & $20 / 80$ \\
\hline KH & $100 / 0$ & $50 / 50$ & $40 / 60$ & $20 / 80$ & $5 / 85$ & $55 / 15$ & $15 / 95$ & $0 / 100$ \\
\hline
\end{tabular}

Однако, наравне с достоинствами, были выделены и некоторые недостатки, в частности: 1) не все студенты понимают цели и задачи данного метода; 2) увеличение времени необходимого для подготовки педагога к занятиям.

\section{Результаты исследования}

Апробированные в настоящем исследовании интерактивные методы в совокупности позволили существенно улучшить результаты обучения. В ходе педагогического эксперимента в контексте темы исследования были созданы две группы студентов 1 и 2 курсов: экспериментальная - (ЭГ, n=18), контрольная - (КГn=17). Апробация ИМ осуществлялась лишь в ЭГ, в то время как в контрольной группе занятия по иностранному языку проводились с использованием традиционных методов обучения. Результаты исследования, полученные по окончанию педагогического эксперимента, были под- вергнуты анализу и интерпретации (см. таблицу 2), что позволило нам сделать экспериментально подтвержденный вывод о действенности ИМ в ходе билингвального построения образовательного процесса в вузе [7].

На основе анализа данной таблицы нами был сделан вывод о том, что обучение студентов дисциплине иностранный язык в неязыковом вузе средствами ИМ является результативным. Примененные в настоящем исследовании ИМ к обучению студентов иностранному языку в неязыковом вузе могут служить в свою очередь основой для разработки и последующей апробации электронно-обучающих курсов (ЭОК) на базе системы дистанционного обучения (СДО). В условиях интенсификации процесса обучения ИМ обучения приобретают особое значение, содействуя активизации учебно-познавательной деятельности студентов, повышая уровень мотивации и интереса к процессу познания, развивая самостоятельность и творческую активность. 


\section{ЛИТЕРАТУРА}

1. Антонова, К.Н. Интерактивное обучение иностранному языку в вузе - СПб, 2006. - 94 с.

2. Ахмедова, Э.М. и др. Использование технологии кейс-стади в образовательном процессе / Э.М. Ахмедова, И.И. Недоповз // Мир науки, культуры, 0бразования. - 2020. - №2 (81). - С.312-314.

3. Блиева, Ж.М. и др. Алгоритм построения интерактивного занятия «мозговой штурм» для студентов-экологов / Ж.М. Блиева, З.П. Оказова // Современные проблемы науки и образования. - 2016. - № 3. [Электронный ресурс]. Режим доступа: http://science-education.ru/ru/article/view?id=24525 (дата обращения: 17.06.2020).

4. Дмитренко, Т.А. Современные технологии иноязычного образования. - М, МГТА, 2018. - 163 с.

5. Захарова, 0.0. Повышение мотивации студентов технического вуза к изучению английского языка средствами лингвистической недели / 0.0. Захарова // Педагогика. Вопросы теории и практики. - 2020. - Т.5. - Вып.2. - С.231-242.

6. Ильина, 0.К. Использование кейс-метода в практике преподавания английского языка / 0.К. Ильина // Лингвострановедение: методы анализа, технология обучения. Шестой межвузовский семинар по лингвострановедению. Языки в аспекте лингвострановедения: сб. научных.статей в 2 ч. Ч. 1. / Под общ. ред. Л.Г. Ведениной. - М.: МГИМО - Университет, 2009. - С. 253-261.

7. К Капустин, И.В. Основные положения билингвальной технологии обучения (БТ0) студентов иностранному языку в условиях неязыкового вуза. (в виде тезисов) / И.В. Капустин // (борник материалов международной научно-практической конференции профессорско-преподавательского состава, посвященной 125-летию со дня рождения В.С. Немчинова ФГБОУ ВО РГАУ-МСХА им. К.А. Тимирязева. - 2019. - С.122-124.

8. Метод case-study: лекции [Электронный ресурс]. Режим доступа: https://www.sites.google.com/site/metodcasestudy/lekcii (дата обращения: 17.06.2020).

9. Методические указания по выполнению кейс-заданий [Электронный ресурс]. Режим доступа: http://volog.ranepa.ru/sveden/docs/education/Metod_Keis. pdf (дата обращения: 17.06.2020).

10. Павленко, В.Г. Применение кейс-метода при обучении английского языка в неязыковом вузе / В.Г. Павленко // Научно-методический электронный журнал «Концепт». - 2016. - Т. 17. - С. 534-538.

11. Постановление Правительства Российской Федерации от 4 октября 2000 г. № 751 г. Москва «0 национальной доктрине образования в Российской Федерации» [Электронный ресурс]. Режим доступа: https://rg.ru/2000/10/11/doktrina-dok.html (дата обращения: 22.06.2020).

12. Семенчук, Ю.А. Интерактивное обучение студентов английской экономической лексике - Тернополь, 2017 - 211 с.

(ㄱ Готовцева Ирина Петровна, Капустин Иван Владимирович, Корзяков Вячеслав Алексеевич (istratown@mail.ru),

Лямина Ирина Мажитовна, Авдеева Ирина Владимировна.

Журнал «Современная наука: актуальные проблемы теории и практики»

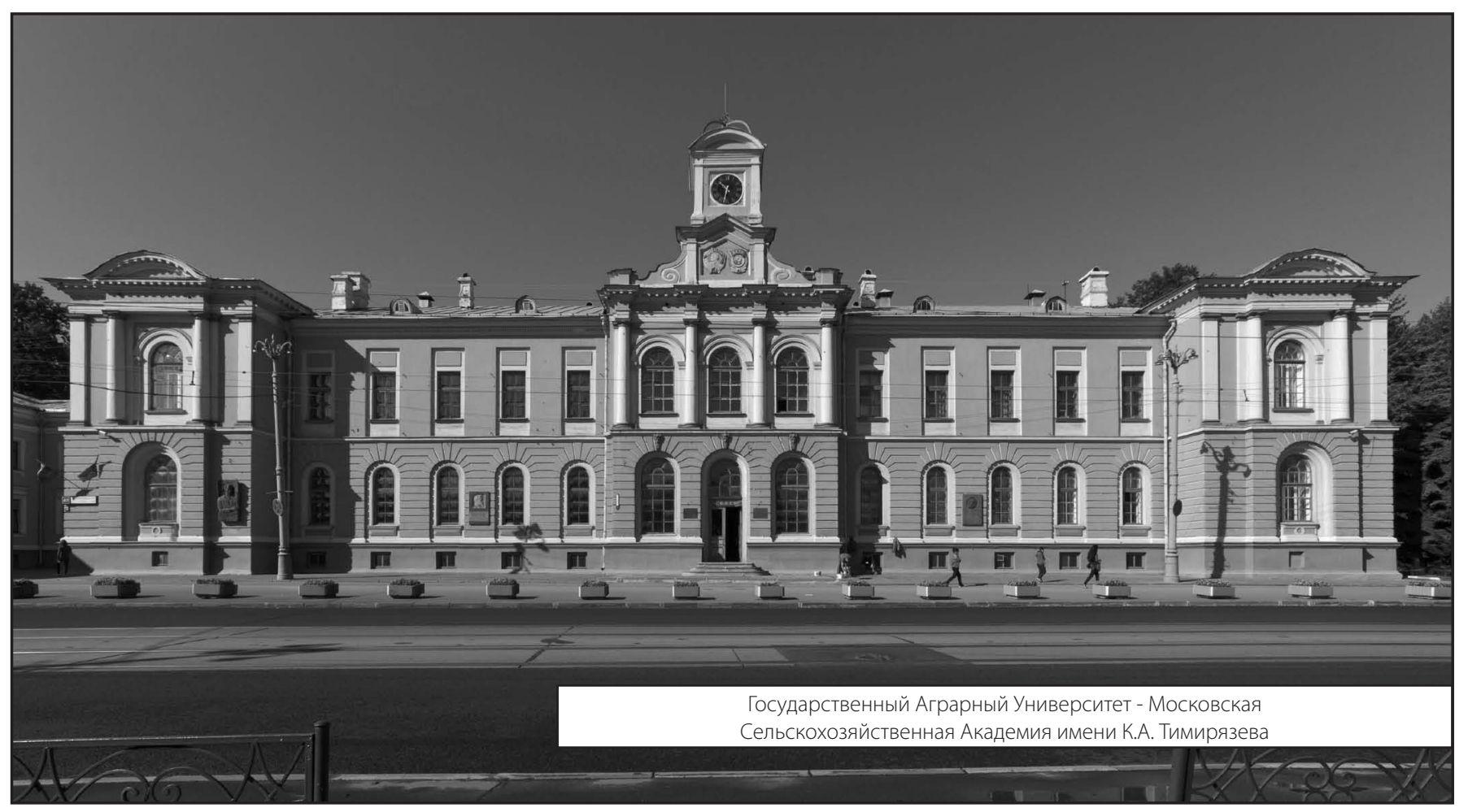

